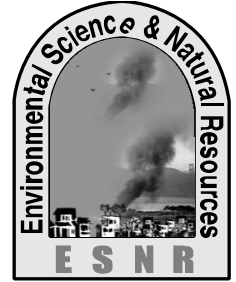

\section{Water Quality Assessment of Some Selected Hatcheries at Shambhuganj Mymensingh}

\author{
M. A. Mou, R. Khatun* and M. A. Farukh
}

Department of Environmental Science, Bangladesh Agricultural University, Mymensingh-2202

*Corresponding author: rehana_envsc@bau.edu.bd

\begin{abstract}
The study was conducted to investigate the physico-chemical parameters and heavy metals content of water in some selected hatcheries at Shambhuganj, Mymensingh. The water samples were collected from seven selected hatcheries during March to April 2019 to examine temperature, EC, TDS, DO, BOD, pH, ammonia, $\mathrm{NO}_{3}{ }^{-}, \mathrm{PO}_{4}{ }^{2-}$ and heavy metals $(\mathrm{Cr}, \mathrm{Cd}$, $\mathrm{Pb}$ and $\mathrm{Ni}$ ). The values of temperature, $\mathrm{pH}$, DO, BOD, EC, TDS and ammonia were $28.5^{\circ} \mathrm{C}, 7.9$ to $8.4,6.8$ to $7.8 \mathrm{mg} \mathrm{L}^{-1}$, 0.1 to $0.9 \mathrm{mg} \mathrm{L}^{-1}, 231.5$ to $307.2 \mu \mathrm{S} \mathrm{cm}^{-1}, 146$ to $200 \mathrm{mg} \mathrm{L}^{-1}$ and 0.04 to $0.06 \mathrm{mg} \mathrm{L}^{-1}$, respectively in the studied hatcheries. The $\mathrm{NO}_{3}{ }^{-}$and $\mathrm{PO}_{4}{ }^{2-}$ content ranged from 0.48 to $0.68 \mathrm{mg} \mathrm{L}^{-1}$ and 0.45 to $0.63 \mathrm{mg} \mathrm{L}^{-1}$, respectively. Among the heavy metals, $\mathrm{Pb}$ was found in 5 hatcheries but the values were within the permissible limit. Other heavy metals $(\mathrm{Cr}, \mathrm{Cd}$ and $\mathrm{Ni})$ were not found in the studied hatcheries. The fish production of the selected hatcheries ranged from 4 to 9 metric ton. The study results revealed that all of the investigated parameters were within the permissible limit and water quality of selected hatcheries was suitable for fish culture.
\end{abstract}

Key words: Anionic properties, Fish production, Heavy metals, Physico-chemical properties

\section{Introduction}

Bangladesh is one of the world's leading inland fisheries manufacturers with a production of $4134434 \mathrm{~m}$. tones during 2015ï2016, with total production from aquaculture of $2333352 \mathrm{~m}$. tones during 2015-2016 (DoF, 2017). This sector is contributing $3.00 \%$ of the total export earnings and $3.61 \%$ to the GDP. Bangladesh has emerged as one of the leading nations in freshwater aquaculture production which ranks fifth among the top 10 aquaculture producing countries of the world (FAO, 2014). However, the natural availability of fish seed and fish has largely gone down and the aquaculture ventures are fully dependent on the hatchery produced fry/fingerling and fish. Due to favorable climatic condition, the highest numbers of hatcheries are located in Mymensingh Division (DoF, 2017).

Quality fish seed and fish production largely depends on quality of water that is pointed as an important factor to success or failure of a fish culture operation (Mayer, 2006). As fish is a cold-blooded animal, it carries out all the body function and physiological needs like respiration, nourishment, feed, maintenance of salt balance and reproduction in water. The physico-chemical and biological characteristics of water play an important role in plankton productivity as well as the biology of cultured organisms and yield. Water quality determines the species abundance under different environments (Dhawan and Kaur, 2002). Good water quality in fish ponds is essential for survival and adequate fish growth
(Burford, 1997). Water quality in fish ponds is affected by the interactions of several chemical components (Wurts and Durborow, 1992). Climate has a major influence on water quality and consequently the biodiversity within the water bodies (Boyd and Tucker, 2012). On the other hand, fish feed and feeding play important role in the sustainable development of aquaculture by influencing the water quality. In view of the above facts, the study was carried out on some selected hatcheries at Shambhuganj, Sadar Upazilla, Mymensingh in order to 1) examine the physicochemical properties of water at selected hatcheries and 2) to assess the fish production status of the selected hatcheries.

\section{Materials and Methods}

\section{Study area}

The study area is located at Shambhuganj, Sadar Upazilla, Mymensingh. It is situated on the other side of the Brahmaputra, connected by the Shambhuganj Bridge and located at the latitude of $24^{\circ} 45^{\prime} 36.18^{\prime \prime} \mathrm{N}$ and the of longitude $90^{\circ} 26^{\prime} 58.29^{\prime \prime} \mathrm{E}$.

\section{Water sample collection and analysis}

The water samples were collected from seven hatcheries: Mukti (H-1), Boishakhi (H-2), Ma (H-3), Brahmaputra (H-4), Ayat (H-5), Vai-Vai (H-6) and Anudan (H-7) during the period from March 2019 to April 2019. Around $500 \mathrm{ml}$ water was collected by pre-prepared sampling bottles from $10 \mathrm{~cm}$ below the surface water at 3 locations of each hatchery. Finally, a composite sample 
was prepared for each hatchery for the analysis of temperature, $\mathrm{pH}$, dissolved oxygen (DO), biochemical oxygen demand (BOD), electrical conductivity (EC), total dissolved solid (TDS), ammonia, nitrate $\left(\mathrm{NO}_{3}{ }^{-}\right)$, phosphate $\left(\mathrm{PO}_{4}{ }^{2-}\right)$ and heavy metals $(\mathrm{Cr}, \mathrm{Cd}, \mathrm{Pb}$ and $\mathrm{Ni})$. Temperature was measured by a Celsius thermometer; $\mathrm{pH}, \mathrm{EC}, \mathrm{TDS}$ and DO was determined by digital $\mathrm{pH}$ meter (Model: pH scan WP 1, 2, Malaysia), EC meter (Model: HM digital, Germany); TDS meter (Model: HM digital, Germany) and DO meter (Model-D, 46974, Taiwan), respectively just after the collection of water samples. The BOD was calculated by: BOD $(\mathrm{ppm})=$ $\left(\mathrm{DO}_{0}-\mathrm{DO}_{5}\right)$, where, $\mathrm{DO}_{0}=$ Initial $\mathrm{DO}$ in the sample, and $\mathrm{DO}_{5}=\mathrm{DO}$ after 5 days. Ammonia was examined by the method of Harwood and Kuhn (1970). Nitrate $\left(\mathrm{NO}_{3}{ }^{-}\right)$ was determined by phenoldisulphonic acid method according to the procedure of Ward et al. (1996). Phosphate $\left(\mathrm{PO}_{4}{ }^{2-}\right)$ was investigated spectrophotometrically by stannous chloride method following the procedure cited by APHA (1995). Heavy metals $(\mathrm{Cr}, \mathrm{Cd}, \mathrm{Pb}$ and $\mathrm{Ni}$ ) were analyzed using Atomic Absorption Spectrophotometer according to standard methods.

Ammonia, $\mathrm{NO}_{3}{ }^{-}$and $\mathrm{PO}_{4}{ }^{2-}$ were investigated in the Laboratory of the Department of Fisheries Management, Bangladesh Agricultural University, Mymensingh and the heavy metals were analyzed in Interdisciplinary Institute for Food Security (IIFS), Bangladesh Agricultural University, Mymensingh. Microsoft office excel 2010 software was used for data analysis and presentation.

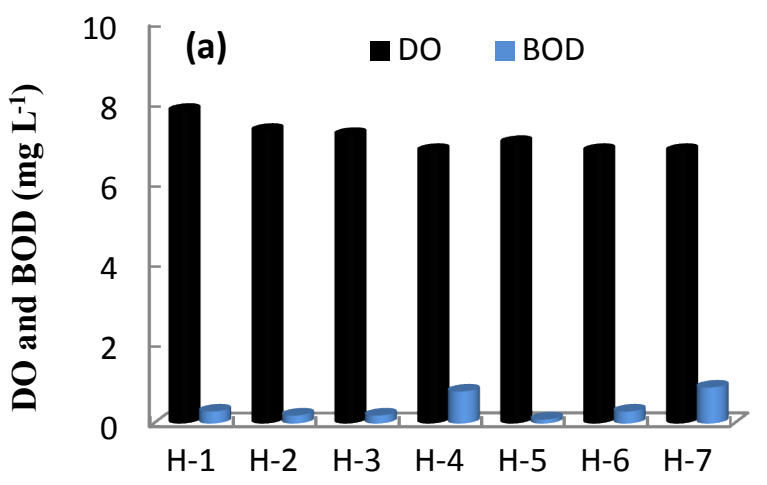

Hatcheries

\section{Results}

Physico-chemical properties of water

The water temperature was $28.5^{\circ} \mathrm{C}$ in all the hatcheries. Dissolve oxygen (DO) in the studied sample ranged from 6.8 to $7.8 \mathrm{mg} \mathrm{L}^{-1}$ (Fig. 1a). The DO of H-1, H-2, H-3, H4, H-5, H-6 and H-7 was 7.8, 7.3, 7.2, 6.8, 7.0, 6.8 and $6.8 \mathrm{mg} \mathrm{L}^{-1}$, respectively. It was highest in $\mathrm{H}-1\left(7.8 \mathrm{mgL}^{-}\right.$ $\left.{ }^{1}\right)$ and lowest in $\mathrm{H}-4\left(6.8 \mathrm{mgL}^{-1}\right), \mathrm{H}-6\left(6.8 \mathrm{mg} \mathrm{L}^{-1}\right)$ and H-7 (6.8 $\left.\mathrm{mg} \mathrm{L}^{-1}\right)$. Biological oxygen demand (BOD) in the studied sample varied from 0.1 ï $0.9 \mathrm{mg} \mathrm{L}^{-1}$ (Fig. 1a). The values of BOD were $0.3,0.2,0.2,0.8,0.1,0.3$ and $0.9 \mathrm{mg} \mathrm{L}^{-1}$ in $\mathrm{H}-1, \mathrm{H}-2, \mathrm{H}-3, \mathrm{H}-4, \mathrm{H}-5, \mathrm{H}-6$ and $\mathrm{H}-7$, respectively. The highest BOD value $\left(0.9 \mathrm{mg} \mathrm{L}^{-1}\right)$ was found in $\mathrm{H}-7$ and the lowest $\left(0.1 \mathrm{mg} \mathrm{L}^{-1}\right)$ was found in $\mathrm{H}$ 5.

In this study, the $\mathrm{pH}$ of seven selected hatcheries ranged from 7.9 to 8.4 (Fig. 1b). The highest $\mathrm{pH}$ was observed in both $\mathrm{H}-1$ (8.4) and $\mathrm{H}-2$ (8.4) whereas the lowest $\mathrm{pH}$ was in both H-4 (7.9) and H-6 (7.9). The value of electrical conductivity (EC) in selected hatcheries ranged from 231.5 to $307.2 \mu \mathrm{S} \mathrm{cm}^{-1}$ (Fig. 1c). The EC values of $\mathrm{H}-1, \mathrm{H}-2, \mathrm{H}-3, \mathrm{H}-4, \mathrm{H} 5, \mathrm{H}-6$ and $\mathrm{H}-7$ were 231.5, 258.01, 239.3, 257.2, 267.3, 307.2 and $281.5 \mu \mathrm{S} \mathrm{cm}$, respectively. The highest EC $\left(307.2 \mu \mathrm{S} \mathrm{cm}^{-1}\right)$ was found in H-6 and the lowest $\left(231.5 \mu \mathrm{S} \mathrm{cm}^{-1}\right)$ was found in $\mathrm{H}-1$. The amount of total dissolved solid (TDS) was 146, 166, 149, 161, 172, 200 and $183 \mathrm{mg} \mathrm{L}^{-1}$ in H-1, H-2, H-3, H4, H-5, H-6 and H-7, respectively (Fig. 1d). The highest (200 $\mathrm{mg} \mathrm{L}^{-1}$ ) TDS was found in $\mathrm{H}-6$, in contrast it was lowest (146 mg L $\left.{ }^{-1}\right)$ in $\mathrm{H}-1$.

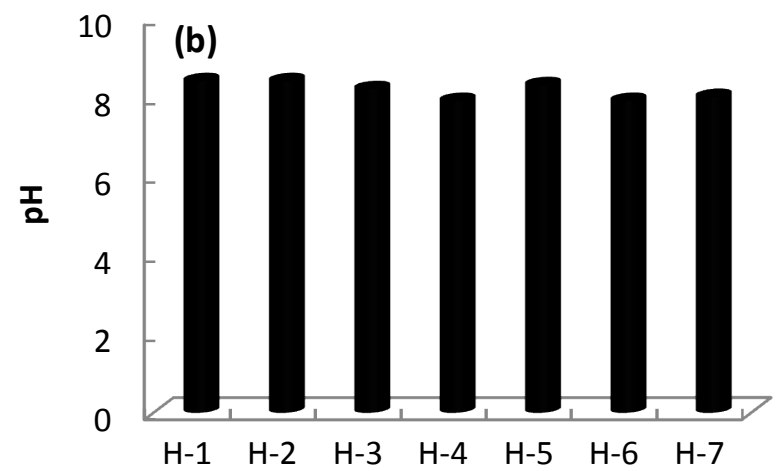

Hatcheries 


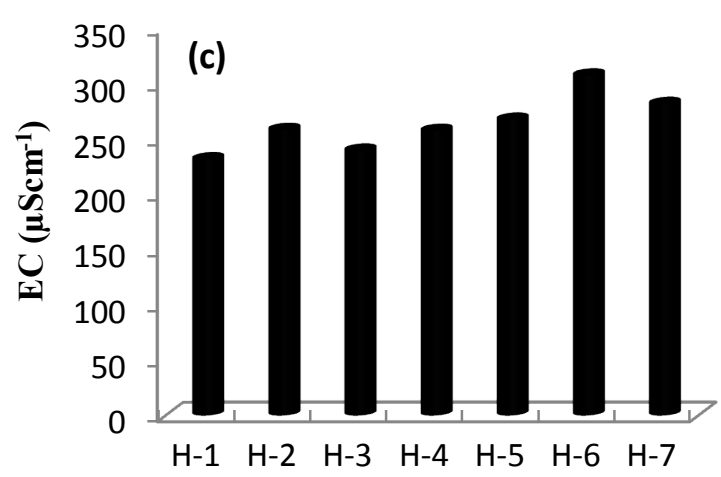

Hatcheries

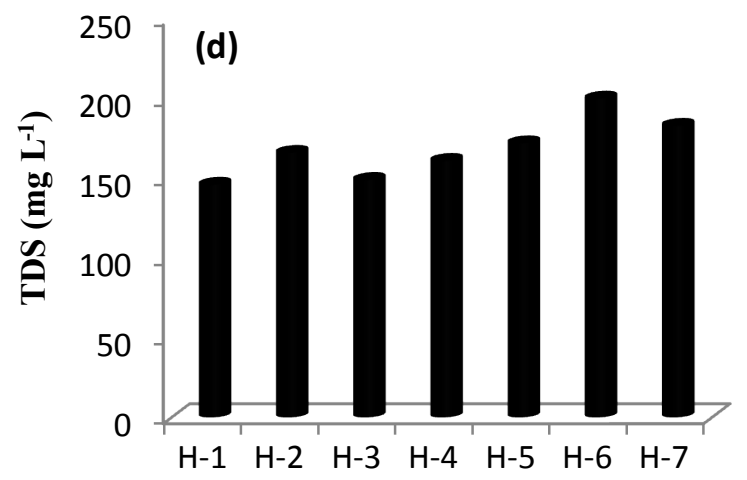

Hatcheries

Fig. 1. Water quality parameters: (a) Dissolve oxygen (DO) and biological oxygen demand (BOD); (b) pH; (c) Electrical conductivity (EC) and (d) Total dissolved solid (TDS) in seven selected hatcheries. Here, H-1= Mukti, H-2= Boishakhi, H3= Ma, H-4= Brahmaputra, H-5= Ayat, H-6= Vai-Vai and H-7= Anudan hatchery

\section{Anionic properties}

The nitrate $\left(\mathrm{NO}_{3}{ }^{-}\right)$content of seven selected hatcheries ranged from 0.48 to $0.68 \mathrm{mg} \mathrm{L}^{-1}$ (Fig. 2a). The $\mathrm{NO}_{3}{ }^{-}$ content of H-1, H-2, H-3, H-4, H-5, H-6 and H-7 was $0.48,0.56,0.54,0.68,0.58,0.62$ and $0.54 \mathrm{mg} \mathrm{L}^{-1}$, respectively. $\mathrm{H}-4$ showed the highest $\left(0.68 \mathrm{mg} \mathrm{L}^{-1}\right) \mathrm{NO}_{3}$ content and the lowest $\left(0.48 \mathrm{mg} \mathrm{L}^{-1}\right)$ was found in $\mathrm{H}-1$.

Phosphate $\left(\mathrm{PO}_{4}{ }^{2-}\right)$ of the studied water samples ranged from 0.45 to $0.63 \mathrm{mg} \mathrm{L}^{-1}$ (Fig. 2a). The values of $\mathrm{PO}_{4}{ }^{2-}$ were $0.45,0.56,0.63,0.55,0.60,0.49$ and $0.50 \mathrm{mg} \mathrm{L}^{-1}$ in
H-1, H-2, H-3, H-4, H-5, H-6 and H-7, respectively. The highest $\left(0.63 \mathrm{mg} \mathrm{L}^{-1}\right) \mathrm{PO}_{4}{ }^{2-}$ was found in $\mathrm{H}-3$ and the lowest $\left(0.45 \mathrm{mg} \mathrm{L}^{-1}\right)$ was found in $\mathrm{H}-1$.

The ammonia content of H-1, H-2, H-3, H-4, H-5, H-6 and $\mathrm{H}-7$ was $0.05,0.06,0.04,0.055,0.044,0.06$ and $0.045 \mathrm{mg} \mathrm{L}^{-1}$, respectively (Fig. $\left.2 \mathrm{~b}\right)$. The highest $(0.06$ $\mathrm{mg} \mathrm{L}^{-1}$ ) ammonia was in H-6 and H-2 whereas the lowest (0.04 $\left.\mathrm{mg} \mathrm{L}^{-1}\right)$ was in $\mathrm{H}-3$.

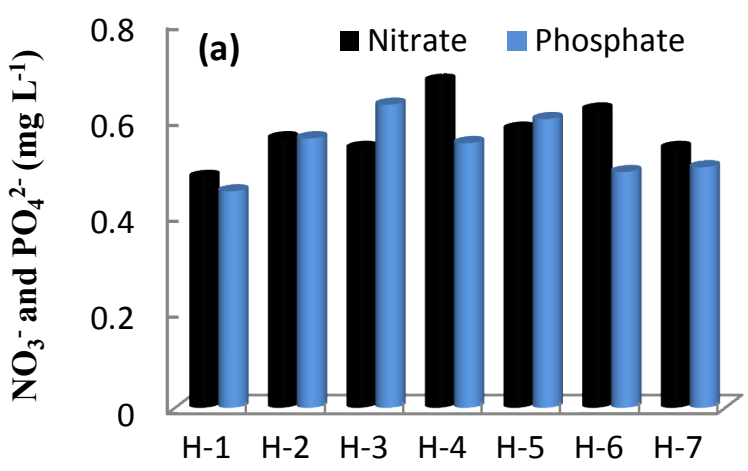

Hatcheries

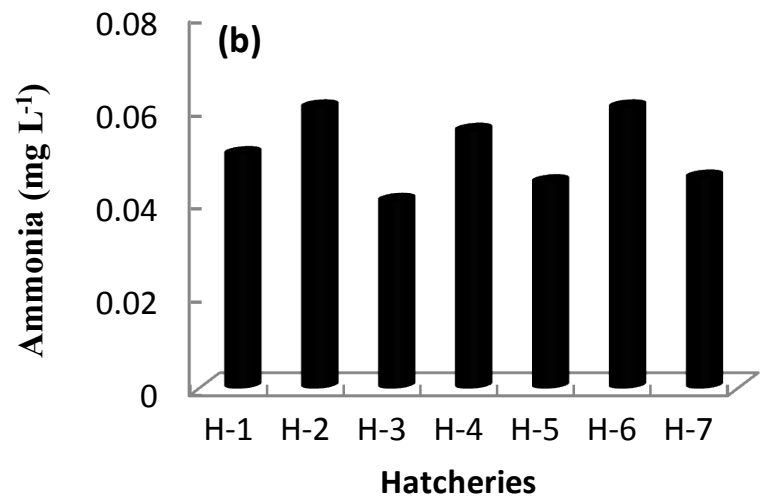

Fig. 2. Anionic properties: (a) Nitrate $\left(\mathrm{NO}_{3}{ }^{-}\right)$and phosphate $\left(\mathrm{PO}_{4}{ }^{2-}\right)$ content and (b) Ammonia content in seven selected hatcheries. Here, H-1= Mukti, H-2= Boishakhi, H-3= Ma, H-4= Brahmaputra, H-5= Ayat, H-6= Vai-Vai and H-7= Anudan hatchery

\section{Heavy metals content}

Nickel (Ni), Chromium (Cr) and $\mathrm{Cd}$ (Cadmium) were undetectable in water of all hatcheries (Table 1). Only lead $(\mathrm{Pb})$ was found in the water of $\mathrm{H}-1(0.0168 \mathrm{ppm})$,
H-2 (0.0042 ppm), H-3 (0.023 ppm), H-4 (0.0179 ppm) and $\mathrm{H}-7$ (0.0265 ppm) and it was undetectable in the water of $\mathrm{H}-5$ and $\mathrm{H}-6$. 
Table 1. Heavy metals content in water of different hatcheries

\begin{tabular}{|c|c|c|c|c|}
\hline \multirow[t]{2}{*}{ Hatcheries } & \multicolumn{4}{|c|}{ Heavy metals (ppm) } \\
\hline & $\mathrm{Ni}$ & $\mathrm{Pb}$ & $\mathrm{Cr}$ & $\mathrm{Cd}$ \\
\hline H-1 & Ò0.1 & 0.0168 & Ò0.01 & Oे0.05 \\
\hline $\mathrm{H}-2$ & Ò0.1 & 0.0042 & Ò0.01 & Ò0.05 \\
\hline $\mathrm{H}-3$ & Ò0.1 & 0.0230 & Ò 0.01 & Ò0.05 \\
\hline $\mathrm{H}-4$ & Ò0.1 & 0.0179 & Ò0.01 & Ò0.05 \\
\hline H-5 & Ò0.1 & Ò0.001 & Òo.01 & Ò0.05 \\
\hline H-6 & Ò0.1 & Ò0.001 & Òo.01 & Ò0.05 \\
\hline $\mathrm{H}-7$ & Ò0.1 & 0.0265 & Òo.01 & Òo.05 \\
\hline
\end{tabular}

Here, H-1= Mukti, H-2= Boishakhi, H-3= Ma, H-4= Brahmaputra, H-5= Ayat, H-6= Vai-Vai and H-7= Anudan hatchery.

\section{Fish production}

Fish production was measured in metric ton (MT) and pond size was measured as acre. Fish production was 4 MT, 8 MT, 7 MT, 6 MT, 4 MT, 9 MT and 5 MT in H-1, $\mathrm{H}-2, \mathrm{H}-3, \mathrm{H}-4, \mathrm{H}-5, \mathrm{H}-6$ and $\mathrm{H}-7$, respectively whereas the pond size was 2 acre, 4 acre, 3 acre, 3 acre, 2 acre, 5 acre and 2 acre in H-1, H-2, H-3, H-4, H-5, H-6 and H-7, respectively (Fig. 3). Highest fish production was in H-6 and was lowest in $\mathrm{H}-1$ and $\mathrm{H}-5$.

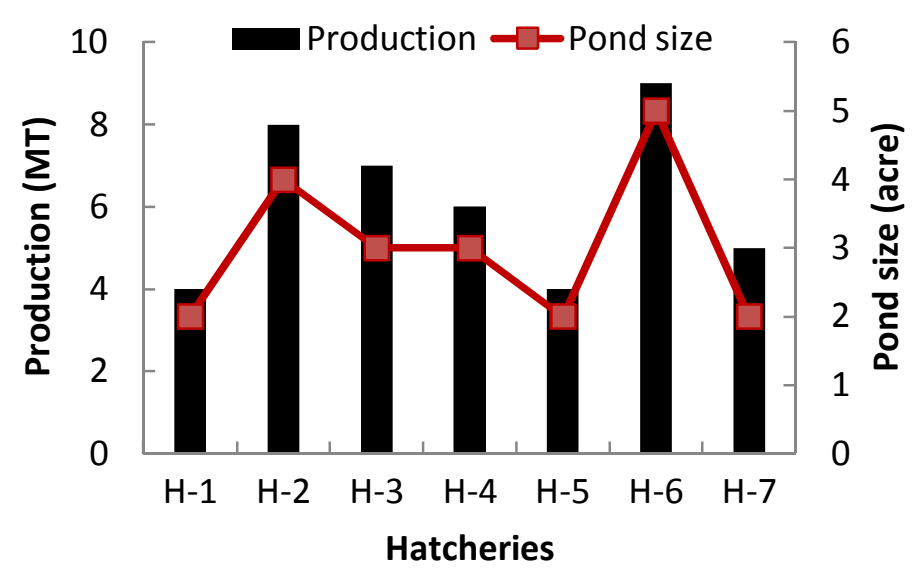

Fig. 3. Fish production and pond size in seven selected hatcheries. Here, $\mathrm{H}-1=$ Mukti, $\mathrm{H}-2=$ Boishakhi, $\mathrm{H}-3=\mathrm{Ma}, \mathrm{H}-4=$ Brahmaputra, H-5= Ayat, H-6= Vai-Vai and H-7= Anudan hatchery

\section{Discussion}

Water temperature is the most important physical variable affecting the metabolic rate of fish and is therefore one of the most important water quality attributes in aquaculture (Kane et al., 2015). Temperature of all studied hatcheries was around $28.5^{\circ} \mathrm{C}$. According to EQS (1997) and De (2005), the optimum temperature of water for fish culture ranges from 20 to $30{ }^{\circ} \mathrm{C}$. Chapman and Kimstach (1992) reported that the higher the temperature, the greater the oxygen and food requirement that leads the faster growth rate of fish. Shyamala et al. (2008) also reported that the range of temperature between 24.75 to $28.5^{\circ} \mathrm{C}$ was suitable for commercial fish production. Dissolved oxygen (DO) is an important environmental parameter for growth, survival, distribution, behavior and physiology of aquatic life. The DO of all studied hatcheries was ranged from 6.8 to $7.8 \mathrm{mg} \mathrm{L}^{-1}$. According to Bhatnagar et al. (2004) and Bhatnagar and Singh (2010), DO level more than 5 $\mathrm{mg} \mathrm{\textrm {L } ^ { - 1 }}$ is essential to support good fish production. Thirupathaiah et al. (2012) reported a range of DO in between 5.18 to $9.72 \mathrm{mg} \mathrm{L}^{-1}$ is good for survival of aquatic organism. DO of all studied hatcheries was good to assist commercial fish production. BOD is the indicator of organic matter in water. Santosh and Singh (2007) recommended the optimum BOD level for aquaculture should be less than $10 \mathrm{mg} \mathrm{L}^{-1}$. The value of BOD in the present study $\left(0.1-0.9 \mathrm{mgL}^{-1}\right)$ is suitable for 
fish production. Aquatic organisms are affected by $\mathrm{pH}$ because most of their metabolic activities are dependent on the value of $\mathrm{pH}$ (Wang et al., 2002). The $\mathrm{pH}$ of seven selected hatcheries ranged from 7.9 to 8.4. The normal range for $\mathrm{pH}$ in surface water is 6.5 to 8.5 (Bhatnagar et al., 2004; Khanom et al., 2014). The result of this study revealed that the $\mathrm{pH}$ level of all studied hatcheries is good for fish production.

The EC is an indicator of total salt concentration in water. The EC values of studied water samples ranged from 231.5 to $307.2 \mu \mathrm{S} \mathrm{cm}$. Stone and Thomforde (2004) recommended that the desirable range of EC is 100 to $2,000 \mu \mathrm{S} \mathrm{cm}^{-1}$ and acceptable range is $30-5,000$ $\mu \mathrm{S} \mathrm{cm} \mathrm{cm}^{-1}$ for fish culture. Therefore, the present values of EC are suitable for fish production.

TDS of water mainly indicates the presence of various minerals and the standard level of TDS for fisheries is about $165 \mathrm{mg} \mathrm{L}^{-1}$ and suitable range is 160 to $200 \mathrm{mg} \mathrm{L}^{-1}$ for growth and production (Huq and Alam, 2005; Rahman et al., 2015). The TDS values of the present study ranged from 146 to $200 \mathrm{mg} \mathrm{L}^{-1}$ and are therefore suitable for aquaculture.

Nitrates are a form of nitrogen and a vital nutrient for growth, reproduction, and the survival of organisms. The nitrate content of seven selected hatcheries ranged from 0.48 to $0.68 \mathrm{mg} \mathrm{L}^{-1}$. Santhosh and Singh (2007) expressed the favorable range of nitrate content is 0.1 to $4.0 \mathrm{mg} \mathrm{L}^{-1}$ for fish culture. Present result was laid between the favorable ranges and is suitable for fish growth and production.

Ammonia is an important parameter of water that regulates the survival of organisms in water. The maximum limit of ammonia concentration for aquatic organisms is $0.1 \mathrm{mg} \mathrm{L}^{-1}$ (Santhosh and Singh, 2007). The ammonia content was 0.04 to $0.06 \mathrm{mg} \mathrm{L}^{-1}$ in the present study which is appropriate for good aquatic environment and commercial growth of fish. Swann (1997) reported that ammonia content ranges from 0.01 to 0.09 is suitable for better fish production and excess ammonia is toxic to culture fish.

Among the heavy metals $(\mathrm{Cd}, \mathrm{Cr}, \mathrm{Ni}$ and $\mathrm{Pb})$, only $\mathrm{Pb}$ was present in minimal amount in five hatcheries that did not hamper the water quality and fish production. Fish production largely depends on water quality as well as size of pond. Usually, fish production increases with the increase of pond size if the water quality parameters are suitable. All the water quality parameters of the studied hatcheries were suitable for fish production and consequently positive correlation was found between the pond size and fish production. Cuenco et al. (1985) stated the effects of interactions among pond size, temperature, dissolved oxygen, unionized ammonia and food on growth of individual fish. They also found a positive correlation between pond size and fish growth.

\section{References}

APHA (American Public Health Association). 1995. Standard Methods for the Examination of water and waste water. $19^{\text {th }}$ end. American Water Works Association (AWWA) \& Water Environmental Federation (WEF). pp. 1-55.

Bhatnagar, A.; Jana, S.N.; Garg, S.K.; Patra, B.C.; Singh, G. and Barman, U.K. 2004. Water quality management in aquaculture, In: Course Manual of summer school on development of sustainable aquaculture technology in fresh and saline waters, CCS Haryana Agricultural, Hisar (India). pp. 203- 210.

Bhatnagar, A. and Singh, G. 2010. Culture fisheries in village ponds: A multi-location study in Haryana, India. Agriculture and Biology Journal of North America 1 (5) 961-968.

Boyd, C.E. and Tucker, C.S. 2012. Pond aquaculture water quality management. Springer Science and Business Media. pp. 700.

Burford, M. 1997. Phytoplankton dynamics in shrimp ponds. Aquaculture Research 28 (5) 351-360.

Chapman, D. and Kimstach, V. 1992. Selection of water quality variables. In: Water assessment: A guide to use of biota, sediments and water in environmental monitoring. $2^{\text {nd }}$ edition.

Cuenco, M.L.; Stickney, R.R. and Grant, W.E. 1985. Fish bioenergetics and growth in aquaculture ponds: II. Effects of interactions among, pond size, temperature, dissolved oxygen, unionized ammonia and food on growth of individual fish. Ecological modeling 27 (3-4) 191-206.

De, A.K. 2005. Environmental chemistry. $5^{\text {th }}$ Edition, New Age International (Pvt.) Ltd., Daryagang, New Delhi, India. pp. 187.

Dhawan, A. and Kaur, S. 2002. Pig dung as pond manure: Effect on water quality, pond productivity and growth of carps in polyculture system. NAGA, the ICLARM quarterly 25 (1) 11-14.

DoF (Department of Fisheries) 2017. Fisheries Resources Survey System, Department of Fisheries, Bangladesh, Dhaka. pp. 81. 
EQS (Environmental Quality Standard). 1997. Bangladesh Gazette, registered nr. DA-1, Ministry of Environment, Government of Bangladesh.

FAO (Food and Agriculture Organization). 2014. The state of world Fisheries and Aquaculture. Department of Fisheries. FAO Fisheries. Technical paper No. 500. FAO, Rome, Italy. pp. 176.

Harwood, J.E. and Kühn, A.L. 1970. A colorimetric method for ammonia in natural waters. Water Research 4 (12) 805-11.

Huq, S.M.I. and Alam, M.D. 2005. A handbook on analysis of soil, plant and water. BACER-DU, University of Dhaka, Bangladesh. pp. 246.

Kane, S.F.; Quarri, P.; Lazo and Bekteshi, L. 2015. The effect of physicochemical parameters and nutrients on fish growth in Narta Lagoon, Albania. Journal of Hygienic Engineering and Degisn 10 62-68.

Khanom, U.S.; Sharmeen, S.; Ferdous, J.; Shumi, W.; Abdu, A.; Hamid, H.A. and Hossain, M.A. 2014. Determination of pond water quality for aquaculture and ecosystem management. Jouranl of Food, Agriculture and Environment 12 (3-4) 389-394.

Mayer, E. 2006. Monitoring pond water quality to improve shrimp and fish production. Herzogenburg, Austria. pp. 5.

Rahman, M. Z.; Zaman, M.F.; Khandokar, S.; Jaman, M.H.; Hossain, M.L. and Bappa, S.B. 2015. Water quality assessment of a shrimp farm: A study in a salinity prone area of Bangladesh. International Journal of Fisheries and Aquatic Studies 2 (5) 09-19.

Santhosh, B. and Singh, N.P. 2007. Guidelines for water quality management for fish culture in Tripura. ICAR Research Complex for NEH Region, Tripura Center, Publication no. 29.
Shyamala, R.; Shanthi, M. and Lalitha, P. 2008. Physicochemical analysis of bore well water samples of Telungupalayam area in Coimbatore District, Tamilnadu, India. Journal of Chemistry 5 (4) 924-929.

Stone, N.M. and Thomforde, H.K. 2004. Understanding your fish pond water analysis report. Cooperative extension program, University of Arkansas at Pine Bluff Aquaculture/Fisheries.

Swann, L.D. 1997. A fish farmerôs guide to understanding water quality, aquaculture extension Illinois, Purdue University, Indiana Sea Grant Program Fact Sheet AS. pp. 503.

Thirupathaiah, M.; Samatha, C.H. and Chintha, S. 2012. Analysis of water quality using physicochemical parameters in lower man air reservoir of Karimnagar district, Andhra Pradesh. International Journal of Environmental Sciences 3 (1) 172-180.

Wang, W.; Wang, A.; Chen, L.; Liu, Y. and Sun, R. 2002. Effects of $\mathrm{pH}$ on survival, phosphorus concentration, adenylate energy charge and $\mathrm{Na}^{+}-\mathrm{K}^{+} \quad$ ATPase activities of PenaeuschinensisOsbeck Juveniles. Aquatic Toxicology 60 75-83.

Ward, M.H.; Mark, S.D.; Cantor, K.P.; Weisenburger, D.D.; Correa-Villasenor, A. and Zahm, S.H. 1996. Drinking water nitrate and the risk of non-Hodgkin's lymphoma. Epidemiology1 46571.

Wurts, W.A.; Durborow, R.M. 1992. Interactions of pH, carbon dioxide, alkalinity and hardness in fish ponds southern regional aquaculture center, SRAC Publication No. 464. pp. 1-3. 